the boy who would be a helicopter 
By the same author

White Teacher

Wally's Stories

Boys and Girls:

Superheroes in the Doll Corner

Mollie Is Three:

Growing Up in School

Bad Guys Don't Have Birthdays:

Fantasy Play at Four

You Can't Say You Can't Play

Kwanzaa and Me:

$A$ Teacher's Story 


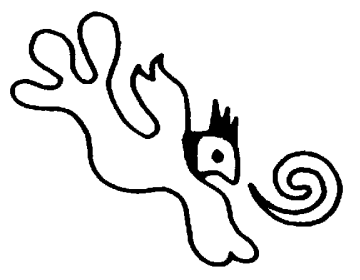

\section{the boy}

who would be

a helicopter

Vivian Gussin Paley

HARVARD UNIVERSITY PRESS

Cambridge, Massachusetts, and London, England 
For Danny, Michelle, and Debbie

\author{
Copyright (C) 1990 by the President and Fellows \\ of Harvard College \\ All rights reserved \\ Printed in the United States of America \\ $\begin{array}{lll}10 & 9 & 8\end{array}$
}

First Harvard University Press paperback edition, 1991

Library of Congress Cataloging-in-Publication Data

Paley, Vivian Gussin, 1929-

The boy who would be a helicopter.

1. Preschool teaching. 2. Teacher-student relationships.

3. Child development. 4. Fantasy in children-Case studies.

I. Title.

LB1140.3.P35 $1990 \quad 372.11^{\prime} 02 \quad 89-24747$

ISBN 0-674-08030-0 (alk. paper) (cloth)

ISBN 0-674-08031-9 (paper)

Designed by Gwen Frankfeldt 